\title{
CHEN YO JIR IN A MEXICAN RESTAURANT
}

Holly Welker

This depiction wants to be more than declarative, wants to comment on the human condition, so the subject is not a rooster, an almond or a groove of bamboo. The subject's name is Chen Yo Jir which is ancient and means "telling stories, has desire." Chen Yo Jir hasn't noticed the orange and fuschia flowers stapled to trellises and on the walls of the dim Mexican restaurant where he is eating tortilla chips and salsa, salt grains scattering off chips onto the table.

He is impervious as well to mariachi music piped in from somewhere and so sitting at the table, he begins to cry think swear hate hum. Chen Yo Jir begins to hum. He knows he's humming off key. He hums the verses and sings the chorus because he forgot to bring a newspaper and still has not noticed the walls thick with many flowers. Right now his name, some old word meaning "Telling stories, has desire" 
seems as much a part of him

as the salt grains falling

from the chips are a part

of the table. He has let us

construct this image around him

and now he is bored

by our attempts to give

his life more meaning than he

ever did, he thinks we

should go to the movies

and leave him alone. 